\title{
Use of Selected Essential Oils for Controlling Stem-end Rot Disease in Mango (cv. Karuthacolomban)
}

\section{Anjali A. Kulasinghe, K. O. L. Chathurika Karunanayake* and S. Somaratne}

Department of Botany, The Open University of Sri Lanka, Sri Lanka

\section{Abstract}

In Sri Lanka, stem-end rot (SER) caused by Lasiodiplodia sp. is the most common and serious disease that affects the mango cv. 'Karuthacolomban'. At present, disease control is achieved with chemical fungicides which are hazardous to human health and environment. As such, this research looked into the possibility of using essential oils (EOs) as biological fungicides against Lasiodiplodia sp. in mango (cv. Karuthacolomban). Pure-grade Basil oil (Ocimum basilicum), Cardamom oil (Elettaria cardamomum), Citronella oil (Cymbopogon nardus L.), Lemon oil (Citrus limon), Mustard oil (Brassica juncea) and Orange oil (Citrus sinensis) were selected for the study. The most effective EOs against Lasiodiplodia sp. under in vitro conditions selected by a poisoned food bio-assay, were used in in vivo studies. The effect of the treatment on reducing disease development, organoleptic properties and the edibility of fruits after in vivo application was assessed. Twenty-four hours after artificial inoculation, fruits were dipped in the selected concentration of the EO solutions at room temperature or at $45^{\circ} \mathrm{C}$ for 3 minutes and then stored under ambient conditions. Disease

* Corresponding should be addressed to Dr. K. O. L. C. Karunanayake, Department of Botany, The Open University of Sri Lanka, Sri Lanka

Email:kokar@ou.ac.lk

(Dttps://orcid.org/0000-0003-0657-9888

(Received 21stOctober 2019; Revised 30th November 2019; Accepted 05th December 2019) (C) OUSL) 
development, percentage weight loss, titrable acidity and total soluble solids contents were measured and a sensory evaluation with a taste panel was also carried out for the treated fruits. Results revealed that basil, cardamom $\left(700 \mu 11^{-1}\right)$ and citronella $\left(400 \mu 1^{-1}\right)$ oils significantly reduced the growth of Lasiodiplodia sp. under in vitro conditions and cardamom oil $\left(700 \mu 1^{-1}\right)$ in warm water effectively reduced the severity of SER under in vivo conditions with no effect on sensory properties or physico-chemical quality parameters. Thus, plant EOs can serve as safe, eco-friendly and effective alternatives to synthetic fungicides.

Key words: Mango, Essential Oil, Stem-End Rot, Lasiodiplodia sp., cardamom oil.

\section{Introduction}

In Sri Lanka, mango is a fruit that is in high demand in the domestic market and an important fruit for the export market (Jayasinghe and Fernando, 2009). However, commercial mango production is constrained by several diseases at all stages of its development. 'Karuthacolomban' (KC), a popular local mango cultivar, develops large stem-end rots caused predominantly by Lasiodiplodia theobromae and it is a major problem in the mango industry in Sri Lanka. (Karunanayake et al., 2013). Stem-end rot of mango is mainly caused by Lasiodiplodia theobromae (Pat.) Griff et Maubl. in tropical Asia (Johnson et al., 1993) and Dothiorella spp., Phomopsis mangiferae, Pestalotiopsis sp. and Cytosphaera mangiferae are also known as causal agents (Johnson et al., 1992) in this process. At present, post-harvest diseases of Mango are controlled by using fungicides (Nascimento et al., 2000). Long term use of agrochemicals has caused serious health hazards to humans and environment in addition to inducing non-target pest and fungicide resistance (Fry, 1982). Thus, adoption of new disease preventive methodology which is safe for humans and environment is needed. Among the various alternatives, natural plant products, including essential oils (EOs) that are biodegradable and eco-friendly, are grabbing the attention of scientists worldwide (Macias et al., 1997). Anthracnose of mango has been effectively controlled using EOs from basil (Ocimum basillicum), orange (Citrus sinensis), lemon (Citrus medica) and mustard (Brassica juncea) (Abd-alla and Haggag, 2013). In Sri Lanka, research 
has been carried out on the use of EOs for the control of post-harvest diseases of banana fruit (Anthony et al., 2003; 2004). Disease control is achieved by the antifungal properties shown by these EOs. Although much research has been carried out regarding controlling anthracnose of mango fruit with EOs, application of EOs to control stem-end rot disease of mango fruit has not been reported in Sri Lanka and limited work (Tripathy and Shukla, 2009) is available internationally. Therefore, in this research, the effects of natural plant products, which are essential oils (EOs) were evaluated as alternatives to fungicides in controlling SER of Mango fruit cultivar 'Karuthacolomban'.

\section{Materials and Methods}

\section{Essential oils}

Pure-grade Essential oils of basil (Ocimum basilicum), cardamom (Elettaria cardamomum), citronella (Cymbopogon nardus), lemon (Citrus limon), mustard (Brassica juncea) and orange (Citrus sinensis) were obtained from Herbal Exotics, Pugoda, Sri Lanka.

\section{Fruits used in the study}

Healthy unripe mango fruits at the harvesting maturity stage were obtained from 'Thabuththegama' $\left(8.15^{\circ} \mathrm{N}, 80.30^{\circ} \mathrm{E}\right)$ within $24 \mathrm{~h}$ of harvest. The fruits were transported to the Botany Research Lab in The Open University of Sri Lanka, washed in running tap water and allowed to dry under ambient conditions. Healthy, unripe fruits of equal size and maturity were used in experiments.

\section{Isolation of the SER pathogen}

The SER pathogen was isolated on to Potato Dextrose Agar (PDA) (Meron Bacteriological Agar, superfine grade) from stem-end rot lesion on ripe K.C. mango fruit following surface sterilization with $0.5 \% \mathrm{NaOCl}$ for 30 seconds. Sub-culturing was performed on the isolated fungi to obtain a pure culture. Sub-culturing was done on to PDA at two weeks intervals and pure cultures of the isolated fungus were maintained. Fungi were identified using colony and conidial morphology. Koch's postulates were performed to confirm the pathogenicity.

\section{In vitro poisoned food bio-assay}

The pure-grade essential oils in the selected concentrations $\left(\mu 11^{-1}\right)$, were 
dispersed individually as an emulsion using Tween $80(0.05 \%)$ and added to flasks containing sterile PDA (at a temperature of $40-45^{\circ} \mathrm{C}$ ) just before pouring to Petri dishes (Pitarokili et al., 2003). Concentrations of EOs between 400 and $1000 \mu 1^{-1}$ were tested and the controls included the same quantity of sterile distilled water. The amount of EO added was adjusted according to the volume of PDA in the flask to obtain the required final concentration. A $5 \mathrm{~mm}$ diameter disk of the test fungal culture was placed in the middle of each plate prepared as mentioned above and incubated at room temperature (RT) $\left(29 \pm 2^{\circ} \mathrm{C}\right)$ (Pitarokili et al., 2003). Linear growth of the fungus was taken by measuring the diameter of the growing culture along two axes (at right angles to each other). Mean growth rates were calculated from three replicate plates of fungi every $24 \mathrm{~h}$ until fungal growth in the control filled the Petri dishes completely. The percentage mycelial inhibition was calculated as described by Tripathi et al. (2008).

\section{In vivo application of essential oil treatment}

A portion of one $\mathrm{mm}^{2}$ mycelial plug from 14-day old Lasiodiplodia sp. culture was placed on top of the stem-end region of mango after making a slight cut on the peel of the fruit at the stem-end (Nisansala et al., 2015). After $24 \mathrm{~h}$ incubation the mycelial plug was removed and fruits were dipped 2-3 min in the effective concentrations of EOs selected based on the in vitro study as a curative treatment. The treatments were: dipping mango fruits in the selected effective concentrations of EOs dissolved in distilled water at RT, or the same EOs and concentrations of EOs in warm water $\left(45^{\circ} \mathrm{C}\right)$ and the controls where mangoes were dipped in distilled water at RT or in warm water $\left(45^{\circ} \mathrm{C}\right)$.

\section{Evaluation of disease development in EO treated fruits}

The infection was identified on the basis of symptoms i.e., a brown, soft decay starting at the stem end and rapidly spreading to the whole fruit. The extent of stem end rot was determined daily up to seven days by tracing the diseased area on to graph paper as described by Karunanayake et al. (2013). 


\section{Effect of the in vivo essential oil treatment on fruit quality parameters}

\section{Physiological Weight Loss (\%)}

Weight loss was determined by daily weighing of fruits for 7 days on digital balance (Radwag, PS6000.R2). The average weights of all fruits in each treatment were taken and at the end of the experiment \% of the weight loss was calculated by the formula of Gerefa et al. (2015).

Physiological weight loss $=\underline{\text { Initial weight of fruits- Final weight of fruits }} \times 100$ Initial weight of fruits

\section{Titrable Acidity (\%)}

To determine titrable acidity, ripe mango fruits (04) from each treatment were selected, peeled and juiced. Form each fruit $10 \mathrm{ml}$ of juice sample was taken (three replicates) and 3 drops of phenolphthalein was added as a $\mathrm{pH}$ indicator. Titration was carried out against $0.1 \mathrm{~N} \mathrm{NaOH}$ until the endpoint turns to pink. Titrable acidity percent as malic acid was calculated by the following formula (Gerefa et al., 2015).

Titrable acidity $(\mathrm{TA} \%)$ as malic acid $=\frac{0.0064 \mathrm{X} \mathrm{ml} \text { of } 0.1 \mathrm{~N} \mathrm{NaOH} \text { consumed }}{\text { Volume of juice }} \times 100$

where 0.0064 is the malic acid conversion factor.

\section{Total Soluble Solids ( ${ }^{\circ}$ Brix)}

To determine total soluble solids (TSS) ripe mango fruits (04) from each treatment were selected and fruit pulp was made into juice without adding water. The Brix value of the pulp of each treatment was recorded using a portable refractometer (Brix/ATC $0 \sim 32 \%$ ) of 0-30 Brix range at $\mathrm{RT}\left(25 \pm 2{ }^{\circ} \mathrm{C}\right)$ and expresses as ${ }^{\circ} \mathrm{Brix}$ (Samane et al., 2012). The readings were taken three times and analyzed.

\section{Sensory evaluation of fruits treated with essential oils}

A panel of untrained 26 adults (aged above 21 years), comprising both male and female, were randomly selected for sensory evaluation. A five point hedonic scale as described by Larmond (1977) was used, where 5 = very high, $4=$ high, $3=$ moderate, $2=$ low and $1=$ very low. The four 
samples were served in identical plates. The organoleptic evaluation of interest conditions were: color (both peel and flesh color) and appearance, texture, odor and taste (Umuhozariho et al., 2013).

\section{Statistical Analysis}

In-vitro experiments were run in triplicate, and data were reported as the mean \pm standard deviation (SD). For the in vivo trials 8 fruits were used per treatment and the experiment was performed thrice. Data were analyzed using a statistical package, IBM SPSS version 20.0. One-way Analysis of variance (ANOVA) among means was performed using one way ANOVA. After applying the least significant Difference (LSD) test, differences of $P \leq 0.05$ were significant. For sensory evaluation data, Principal Component Analysis (PCA) and cluster analysis were used to identify the preferences of the panelists for the samples.

\section{Results}

\section{Isolation of the SER pathogen}

The mycelia grew uniformly in all directions and fully covered the surface of the media within 3 to 4 days. The colour of the colony changed gradually from light grey to dark gray after four to seven days of incubation and to greyish black after 2 weeks of incubation (Figure 1). Mature conidia were observed to have one septa, oval-shaped and brown in colour with the presence of irregular longitudinal striations (Figure 2). The identity of the fungus was confirmed as Lasiodiplodia sp. Based on colony and conidial morphology. Pathogenicity was confirmed by Koch's postulates. 


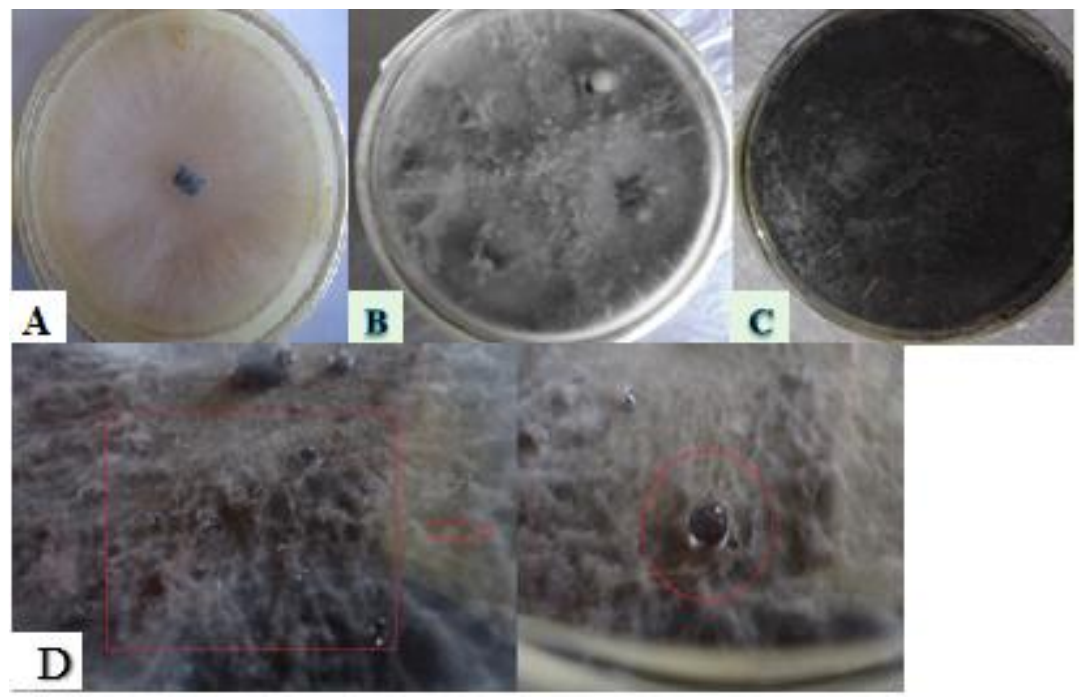

Figure 1: Colony characteristics of the fungus isolated from Mango (K.C.) fruit. (A). Top view (day 2); (B). Top view of colony (day 4); (C). Top view of colony (day 14); (D). Developing fruiting bodies (after 14 days).
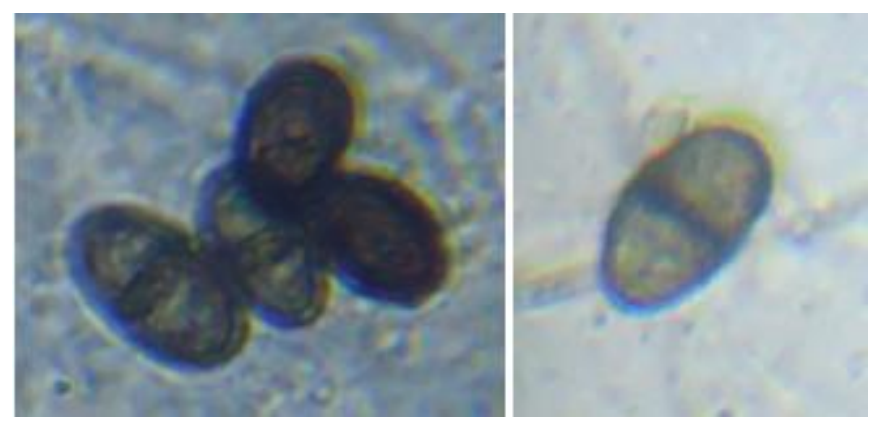

Figure 2. Conidial morphology of Lasiodiplodia sp. under light microscope (high power: 400x magnification).

\section{In vitro poisoned food bio-assay}

Of the six selected EOs Lemon, orange and mustard were not effective in inhibiting growth of Lasiodiplodia sp. under in vitro conditions (LSD $\mathrm{p}>0.05$ ). Basil, cardamum and citronella oils showed a significant effect (LSD $\mathrm{p}=0.00$ ) on mycelial growth where cardamom oil was found to be the most effective $\left(67.7 \%\right.$ inhibition) at $700 \mu 11^{-1}$ (Table 1$)$. 
Table 1. Percentage mycelial inhibition of Lasiodiplodia sp. in PDA media treated with different concentrations of essential oils by the time control cultures reached maximum growth ( $90 \mathrm{~mm}$ colony diameter).

\begin{tabular}{|l|l|l|}
\hline $\begin{array}{c}\text { Essential oil } \\
\text { Treatment }\end{array}$ & Concentration $\left(\mu 11^{-1}\right)$ & Inhibition (\%) \\
\hline \multirow{2}{*}{ Basil } & 600 & $46.50 \pm 14.9$ \\
\cline { 2 - 3 } & 700 & $60.71 \pm 13.3$ \\
\hline \multirow{2}{*}{ Cardamom } & 600 & $30.14 \pm 6.29$ \\
\cline { 2 - 4 } & 700 & $67.69 \pm 13.9$ \\
\hline \multirow{2}{*}{ Citronella } & 400 & $52.41 \pm 17.2$ \\
\cline { 2 - 4 } & 500 & $57.31 \pm 14.53$ \\
\hline
\end{tabular}

Evaluation of disease development in fruits following in vivo application of Essential oils

In the in vivo treatment, the most effective is the cardamom in hot water treatment. Mean area of disease development was significantly lower in hot water dipped cardamom oil treated fruits, 72 hours after treatment (HAT), 96 HAT and 120 HAT when compared with the control. Disease development is high in basil-treated fruits than in control fruits at 72 HAT and 96 HAT (Figure 3). 


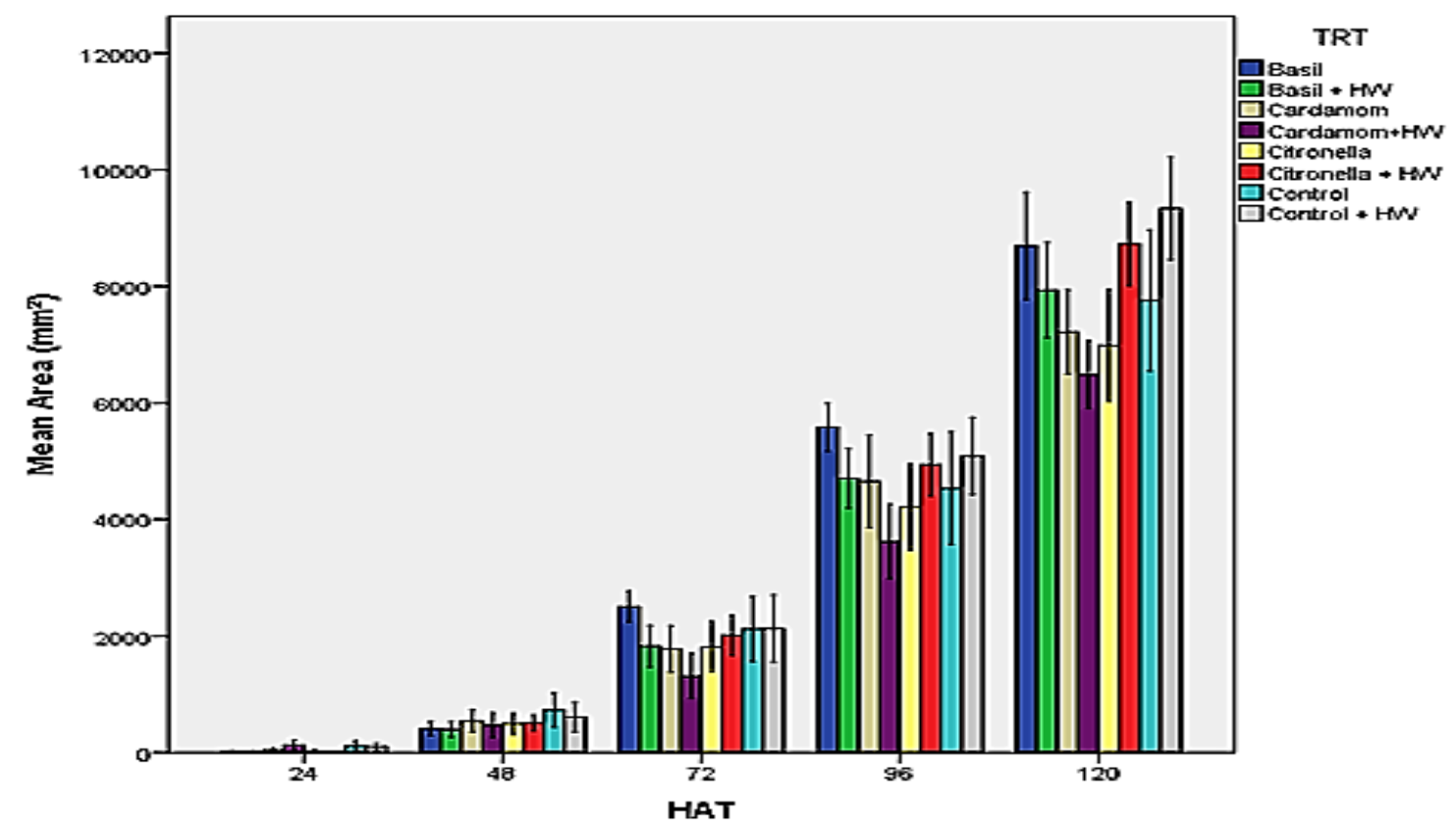

Figure 3. Mean disease area $\left(\mathrm{mm}^{2}\right)$ of 14 replicates of 'K.C.' fruits inoculated with $L$. theobromae and then treated with 3 selected EOs. Error bars represent the standard error of the means.

Mean area $=$ diseased development in 14 replicates, $\mathrm{TRT}=$ Treatment, HAT $=$ Hours after treatment, HW $=$ EOs in hot water at $\left(45^{\circ} \mathrm{C}\right)$.

Effect of the in vivo essential oil treatment on physico-chemical parameters: physiological weight loss, Titrable acidity and TSS

The lowest \%weight loss was seen in cardamom + HW treatment (Day 6: 1.52g, Day 7: 2.00g) while the highest was in the control + HW (Day 6: 2.25 and Day $7: 2.7 \mathrm{~g})$. There was no significant difference in ${ }^{\circ}$ Brix value among the treatments. However, the value was slightly higher in the control (13.25) compared to the effective cardamom treatments (cardamom 12.05, cardamom + HW 12.81) and the control + HW 12.55. There was no significant difference between the \%Titrable acidity among treatments. 


\section{Sensory evaluation of fruits treated with essential oils}

The Principal Component Analysis (PCA) extracted three components explaining a total variance of $51.541 \%$ of the total data set. The result of the PCA revealed that the treatment did not affect the taste of the fruits. However, treatment negatively affected the appearance, peel color, hardness and freshness of treated fruits (LSD p=0.00) (Table 2).

The most effective oil for reducing the growth of Lasiodiplodia sp. under in vivo condition was cardamom oil. As a treatment, cardamom oil in hot water was more inhibitory on the SER pathogen and rendered lower physiological weight loss in fruits compared to all the other treatments. According Olivero-Verbel et al. (2010) and Utta-U'r et al. (2000) inhibitory effect of cardamom essential oil on fungi maybe due to 1,8-cineol $(29.7 \%)$ and a-terpineol acetate $(26.1 \%)$ the main components found in the volatile oil. Hot water treatment is known to be an effective and environmental-friendly method for controlling postharvest diseases of mango (Kumah et al., 2011; Duamkhanmanee, 2008). Therefore, in the present study the EO with fungicidal components and the hot water treatment which can also control post-harvest diseases would have in combination brought about the significant reduction in SER in treated mango fruits. 
Table 2. Summary of the Principal Component Analysis (PCA) carried out on the sensory data of treated fruits

\begin{tabular}{lccc}
\hline & \multicolumn{3}{c}{ Component } \\
\cline { 2 - 4 } & $\mathbf{1}$ & $\mathbf{2}$ & $\mathbf{3}$ \\
\hline Eigen value & $\mathbf{1 . 8 8 9}$ & $\mathbf{1 . 3 7 9}$ & $\mathbf{1 . 3 7 0}$ \\
\% variance explained & $\mathbf{2 0 . 9 9 4}$ & $\mathbf{1 5 . 3 2 5}$ & $\mathbf{1 5 . 2 2 2}$ \\
Total variance explained & $\mathbf{2 0 . 9 9 4}$ & $\mathbf{3 6 . 3 1 9}$ & $\mathbf{5 1 . 5 4 1}$ \\
& & & \\
Appearance & & & \\
Peel Color & $\mathbf{0 . 6 9 7}$ & -0.116 & -0.062 \\
Hard & $\mathbf{0 . 6 5 2}$ & 0.212 & 0.155 \\
Fresh & $\mathbf{0 . 6 2 0}$ & 0.080 & -0.074 \\
Soft & $\mathbf{0 . 5 3 7}$ & -0.065 & 0.466 \\
Flesh Color & 0.040 & $\mathbf{- 0 . 6 8 5}$ & 0.221 \\
Sweet & -0.017 & $\mathbf{0 . 6 6 4}$ & 0.285 \\
Dry/Wrinkled & 0.141 & $\mathbf{0 . 6 1 8}$ & 0.100 \\
Fruity & -0.324 & 0.074 & $\mathbf{0 . 7 3 8}$ \\
\hline
\end{tabular}

\section{Discussion}

The most effective essential oils for reducing the growth of the SER pathogen Lasiodiplodia sp. under in vitro conditions were cardamom oil, basil oil and citronella oil. Although citronella oil was effective in controlling pathogen, it was not used in the in-vivo experiment due to its strong and unpalatable aroma. The antimicrobial activity of basil against various microbes has been reported in previous studies (Bozin et al., 2006; Sokovic and Griensven, 2006) and many scientists have linked basil antimicrobial effects to the presence of high content of linalool which is the main component of the oil (Juliani and Simon, 2002).

In the present study, the highest Brix value was seen in the control 
fruits. However, all treatments demonstrated TSS over 10\% Brix which is an acceptable sugaur content for mango fruit (Harrill, 1998). Therefore, the treatment did not negatively affect the sugar content of the fruit. Though the taste of fruits under focus was not affected by the oil application, PCA data revealed that treatment did affect the appearance, peel color and hardness of the fruit all of which are important determinants of marketing the fruit. This is a negative aspect of EO treatment as the outer appearance is a major parameter for consumer acceptability.

Overall, these findings suggest that cardamom EO can be used to control the postharvest losses caused by Lasiodiplodia sp. in the mango cultivar 'Karuthacolomban' fruit. However, the method of application needs slight modifications to overcome the negative effects of $\mathrm{EO}$ on the outer appearance of the fruit. Incorporation of EOs into edible waxes and other fruit coatings may be a suitable alternative to hot-water-dip treatments.

\section{Conclusions}

Essential oils of cardamom (Elettaria cardamomum) are an effective and environmentally safe alternative to synthetic fungicides in controlling the stem-end rot caused by Lasiodiplodia sp. in mango fruit cultivar 'Karuthacolomban' with no detrimental effects on sensory quality.

\section{Acknowledgments}

Financial assistance from Faculty Research Grant, Faculty of Natural Sciences, OUSL -2016 is acknowledged

\section{References}

Abd-alla, M. A. \& Haggag, W. M. (2013). Use of some essential oils as Postharvest botanical fungicides in the management of anthracnose disease of mango fruits caused by Colletotrichum gloeosporioides. International Journal of Agriculture and Forestry, 3(1), 1-6. DOI: $10.5923 /$ j.ijaf.20130301.01 
Anthony, S., Abeywickrama, K. \& Wijeratnam, S.W. (2003). The effect of spraying essential oils of Cymbopogon nardus, Cymbopogon flexuous and Ocimum basilicum on postharvest diseases and storage life of Embul banana. Journal of Horticultural Science and Biotechnology, 78 (6), 780-785.

https://doi.org/10.1080/14620316.2003.11511699

Anthony, S., Abeywickrama, K., Dayananda, R., Wijeratnam, S.W. \& Arambewela, L. (2004). Fungal pathogens associated with banana fruit in Sri Lanka and their treatment with essential oils. Mycopathologia, $157 \quad$ (1), 91-97. DOI: 10.1023/b:myco.0000012226.95628.99

Bozin, B., Mimica-Dukie, N., Simin, N. \& Anackov, G. (2006). Characterization of the volatile composition of essential oils of some Lamiaceae spices and the antimicrobial and antioxidant activities of entire oils. Journal of Agricultural and Food Chemistry, 54, 18221828. DOI: $10.1021 /$ jf051922u

Duamkhanmanee, R. (2008). Natural essential oils from lemon grass (Cymbopogon citratus) to control post-harvest anthracnose of mango fruit. International Journal of Biotechnology, 1, 104-108. https://doi.org/10.1504/IJBT.2008.017971

Fry, W. E. (1982). Principals of plant disease management, Academic press, New York, p.377.

Gerefa, S., Satheesh, N. \& Berecha, G. (2015). Effect of essential oils treatment on anthracnose (Colletotrichum gloeosporioides) disease development, quality and shelf life of mango fruits (Mangifera indica L). American-Eurasian Journal of Agricultural \& Environmental Science, 15 (11), 2160-2169.

DOI: 10.5829/idosi.aejaes.2015.15.11.96140

Harill, R. (1998). Using a refractometer to test the quality of fruits \& vegetables.(2nd ed.). Keedys Villle, Madagascar: Pink noll Publishing.

Jayasinghe, C. K. \& Fernando, T. H. P. S. (2009). First report of Colletotrichum acutatum on Mangifera indica in Sri Lanka. Ceylon Journal of Science (Bio.Sci.), 38(1), 31-34.

http://doi.org/10.4038/cjsbs.v38i1.1326

Juliani, H. R. \& Simon, J. E. (2002). Antioxidant Activity of Basil. Trends in new crops and new uses. J. Janick and A. Whipkey (eds.). ASHS 
Press, Alexandria, $\quad$ VA., 5p. 575-579. https://www.hort.purdue.edu/newcrop/ncnu02/v5-575.html

Johnson, G.I., Mead, A.J., Cooke, A.W. \& Dean, J.R. (1992). Mango stem-end rot pathogens-fruit infection by endophytic colonization of the inflorescence and pedicel. Annals of Applied Biology, 120, 225234.

https://doi.org/10.1111/j.1744-7348.1992.tb03420.x

Johnson, G., Cook, T \& Mead, A. (1993). Infection and quiescence of mango stem-end rot pathogens. Proceedings IV international Mango symposium in Acta Horticulturae, 341.

Karunanayake, K. O. L. C., Sinniah, G. D., Adikaram, N. K. B. \& Abayasekara, C. (2013). Cultivar differences in antifungal activity and the resistance to postharvest anthracnose and stem-end rot in mango (Mangifera indica L.). Australasian Plant Pathology, 43, 151159. DOI $10.1007 / \mathrm{s} 13313-013-0257-4$

Kumah, P., Applah, F. \& Opoku-Debrah, J. K. (2011). Effect of hot water treatment on quality and shelf-life of Keitt mango. Agriculture and Biological Journal of North America, 2(5), 806-817. Doi:10.5251/abjna.2011.2.5.806.817

Larmond, E., (1977). Laboratory methods for sensory Evaluation of food, Canada Department of Agriculture.

Macias, F. A., Castellano, D., Oliva, R. M., Cross, P \& Torres, A. (1997). Potential use of allelopathic agents as natural agrochemicals, Proceedings of Brighton Crop Protection Conference Weeds, pp.3338 Brighton, UK.

Nascimento, S. R. C., Araujo-Neto, S. E. \& Hafle, G. M. (2000). Use of prochloraz, azoxystrobin and sodium bicarbonate for the postharvest control of Colletotrichum gloeosporioides. Summa Phytopathologica, 26(3),379-382.

Nisansala, Y. M. C., Jayakody, L.K.R.R., Sarananada, H.A. \& Somarathne, S. (2015). Effect of pre-harvest potassium treatment on stem-end rot disease development in mango (Mangifera indica $\mathrm{L}$ ) cv. Tom EJC during fruit ripening. Sabaragamuwa University Journal, 14 (2), 119-132.

DOI: http://dx.doi.org/10.4038/suslj.v14i2.7700 
Olivero-Verbel, J., González-Cervera, T., Güette-Fernandez, J., Jaramillo-Colorado, B. \& Stashenko, E. (2010). Chemical composition and antioxidant activity of essential oils isolated from Colombian plants. Brazilian Journal of Pharmacognosy, 20, 568574.

http:/ /dx.doi.org/10.1590/S0102-695X2010000400016

Pitarokili, D., Tzakou, O., Loukis, A. \& Harvala, C. (2003). Volatile metabolite from Salvia fruticosa as antifungal agents in soilborn pathogens. Journal of Agriultural and Food Chemistry, 51(11), 32943301. https://doi.org/10.1021/jf0211534

Samane, M. \& Mohoammad, H. (2012). Effect of essential oils on postharvest decay and some quality factors of peach (Prunus persica) var. Redhaven. Journal of Biological Environmental Science, 6, 147153.

https://pdfs.semanticscholar.org/4fff/788858dfdbd70f7fdd260847d33 fbaa55a5c.pdf (accessed on 15/07/2017)

Sokovic, M. \& Griensven, L. J. L. D. V. (2006). Antimicrobial activity of essential oils and their components against the three major pathogens of the cultivated button mushroom, Agaricus bisporus. European Journal of Plant Pathology, 116, 211-224. DOI 10.1007/s10658-006-9053-0

Tripathi, P., Dubey, N. K. \& Shukla, A. K. (2008). Use of some essential oils as post-harvest botanical fungicides in the management of grey mould of grapes caused by Botrytis cinerea. World Journal of Microbial Biotechnology, 24, 39-46. DOI 10.1007/s11274-007-94352

Tripathi, P. \& Shukla, A. K. (2009). Application of essential oils for postharvest control of stem end rot of mango fruits during storage. International Journal of Postharvest Technology and Innovation 1 (4), 405-415. DOI:10.1504/IJPTI.2009.030689

Umuhozariho, M. G., Shayo, N. B., Sallah, P. Y. K. \& Msuya, J. M. (2013). Sensory evaluation of different preparations of cassava leaves from three species as a leafy vegetable. African Journal of Biotechnology, 13(46), 6452-6459. DOI: 10.5897/AJB2013.12490 
Utta-U`r, R., Choudhary, M. I., Ahmed, A., Iqbal, M. Z., Demirci, B., Demirci, F. \& Baser, K. H. C. (2000). Antifungal activity and essential oil constituent of some spices from pakistan. Journal of Chemistry Society of Pakistan, 22, 60-65. https://sciforum.net/manuscripts/1773/original.pdf (accessed on 20/08/2017) 